\title{
A HISTORY OF HOST ASSOCIATIONS AND EVOLUTIONARY DIVERSIFICATION FOR OPHRAELLA (COLEOPTERA: CHRYSOMELIDAE): NEW EVIDENCE FROM MITOCHONDRIAL DNA
}

\author{
DANIEL J. Funk, ${ }^{1}$ DOUglas J. Futuyma, \\ Guillermo Ortí, AND AXEl MEYER \\ Department of Ecology and Evolution, State University of New York, Stony Brook, New York 11794
}

\begin{abstract}
Key words.-Character reconstruction, Chrysomelidae, coevolution, cospeciation, host shifts, insect-plant interactions,
\end{abstract} Ophraella, peripatric speciation, phylogeny, phylogeography.

A rapidly growing supply of phylogenetic trees has fueled a burst of insights into the ways that phylogenetic data might inform our study of evolution (e.g., Lauder 1990; Wanntorp et al. 1990; Brooks and McLennan 1991; Harvey and Pagel 1991; Swofford and Maddison 1992). One area in which these approaches have proven particularly useful is the study of coevolution (Mitter and Brooks 1983; Brooks 1988; Miller 1991; Mitter et al. 1991; Brooks and McLennan 1993), the cladogenetic and selective influences that ecologically coupled taxa exert on each other through evolutionary time. Those who study the coevolution of herbivorous insects and their host plants have repeatedly noted both the relative host specificity of most herbivore species and the taxonomic conservatism that often characterizes the host affiliations of insect genera and families (Dethier 1954; Ehrlich and Raven 1964; Ward and Spalding 1993). Certain explanations for these patterns can be tested phylogenetically.

For example, if herbivore lineages remain strictly associated with their host species over sufficient periods of evolutionary time, vicariance events that isolate populations of the host will also isolate populations of the herbivore. To the extent that these events lead to the formation of new species, this combination of host loyalty and parallel cladogenesis (Benson et al. 1975; Mitter and Brooks 1983; Spencer 1988) can account for both host specificity and host conservatism. If this allopatric cospeciation scenario (Brooks 1979) holds, the phylogenies of host plant taxa and their insect parasites will be at least roughly concordant. Topological contradictions between these trees, however, suggest that herbivore lineages have switched their affinities from one plant group to another subsequent to the diversification of these plants (Jermy 1984; Brooks 1988). To date, most of the handful of pertinent studies (reviewed in Mitter and Farrell 1991) have found evidence for such host shifts, but a few notable exceptions are strongly consistent with the cospeciation model (Farrell and Mitter 1990; B. Farrell in prep.).

But if host shifts commonly occur, why do they involve the particular (and often related) plant species that they do, given that selection pressures favoring the use of locally common nonhosts must be omnipresent (Futuyma 1983)? Such conservatism suggests that the spectrum of likely host shifts may be limited by constraints on adaptively relevant genetic variation, perhaps because of the host associations of an her-

${ }^{1}$ E-mail: danfunk@life.bio.sunysb.edu. bivore lineage. For instance, the apparent role of plant chemistry in determining herbivore host affiliations (reviewed in Feeny 1992) might be largely explained by the minimally novel genetic variation required for shifts between chemically similar hosts.

We have adopted an historically informed approach to investigate the degree to which such genetic constraints can explain the host associations of the leaf beetle genus Ophraella (Futuyma 1992; Futuyma et al. 1993, 1994). These studies were initiated by optimizing host affiliations on the phylogeny of Ophraella (Maddison and Maddison 1992) in order to infer a history of host associations. Ophraella species with various histories of host use were then screened for genetic variation in performance on several hosts of their congeners to test the role that constraints on this variation might play in guiding the evolution of host shifts (Futuyma and Keese 1992; Futuyma et al. 1993, 1994, 1995). Futuyma et al. (1995) summarize and interpret the genetic data in the phylogenetic context reported in this paper. This research program thus represents a synthesis of phylogenetic and population biological approaches.

A phylogeny for these studies was first provided by the analysis of morphological and allozyme characters (Futuyma and McCafferty 1990, hereafter referred to as F\&M). However, although F\&M reported the resolution of Ophraella into three major clades, the relationships among the closely related species in the largest clade remained unclear. The importance of these unresolved relationships for interpreting the experimental work prompted the recent collection of rapidly evolving mitochondrial DNA (mtDNA) sequences. These data have been analyzed alone and in combination with the morphology and allozyme data to provide a more compelling estimate of Ophraella phylogeny. Here, we briefly report the results of this work, presented in full by Funk et al. (1995).

In this paper, we employ this new phylogenetic estimate to infer the history of Ophraella host associations at two taxonomic levels. We then evaluate our confidence in these results with reference to the ambiguities of character reconstruction, and discuss the insights and reinterpretations they provide about the history of host use. Unanticipated conclusions about the tempo and mode of Ophraella diversification are drawn from our genetic, phylogenetic, biogeographic, and host use data. In a companion paper, the new estimate of phylogeny is used to interpret the experimental studies on genetic constraints (Futuyma et al. 1995). 
TABLE 1. Geographical distributions and known host associations of species in this study. Abbreviations used in table 2 follow species' names. Abbreviations for states in the United States are used. Asteraceous tribes that include Ophraella hosts are abbreviated as follows: ANT, Anthemideae; AST, Astereae; EUP, Eupatorieae; HEL, Heliantheae. Further details on host records may be found in Futuyma (1990). Distributions are from LeSage 1986 and the personal records of D. Futuyma.

\begin{tabular}{|c|c|c|}
\hline Species & Distribution & Host plants \\
\hline \multicolumn{3}{|l|}{ Ophraella } \\
\hline arctica LeSage (arc) & Arctic Canada & AST: Solidago multiradiata \\
\hline artemisiae Futuyma (art) & W Tex., Ariz., Minn. & ANT: Artemisia carruthii, A. ludoviciana \\
\hline communa LeSage (com) & S Canada to S Mexico throughout & $\begin{array}{l}\text { HEL: Ambrosia artemisiifolia, A. psilostachya, Iva axillaris, } \\
\text { Parthenium hysterophorus, Xanthium strumarium; Helian- } \\
\text { thus ciliaris }\end{array}$ \\
\hline notata (Fabricius) (not) & E U.S. & $\begin{array}{l}\text { EUP: Eupatorium perfoliatum, E. maculatum, E. hyssopifol- } \\
\text { ium, E. capillifolium }\end{array}$ \\
\hline notulata (Fabricius) (ntl) & $\begin{array}{l}\text { Atlantic and Gulf coasts; scattered in- } \\
\text { land records }\end{array}$ & HEL: Iva frutescens, I. annua \\
\hline nuda LeSage (nud) & SE Alberta & HEL: Iva axillaris \\
\hline pilosa LeSage (pil) & U.S. and S Canada, E of Rocky Mts. & $\begin{array}{l}\text { AST: Aster macrophyllus, A. urophyllus, A. Lowrieanus, A. } \\
\text { novae-angliae, A. cordifolius, A. paniculatus, Solidago bi- } \\
\text { color, } S . \text { squarrosa }\end{array}$ \\
\hline
\end{tabular}

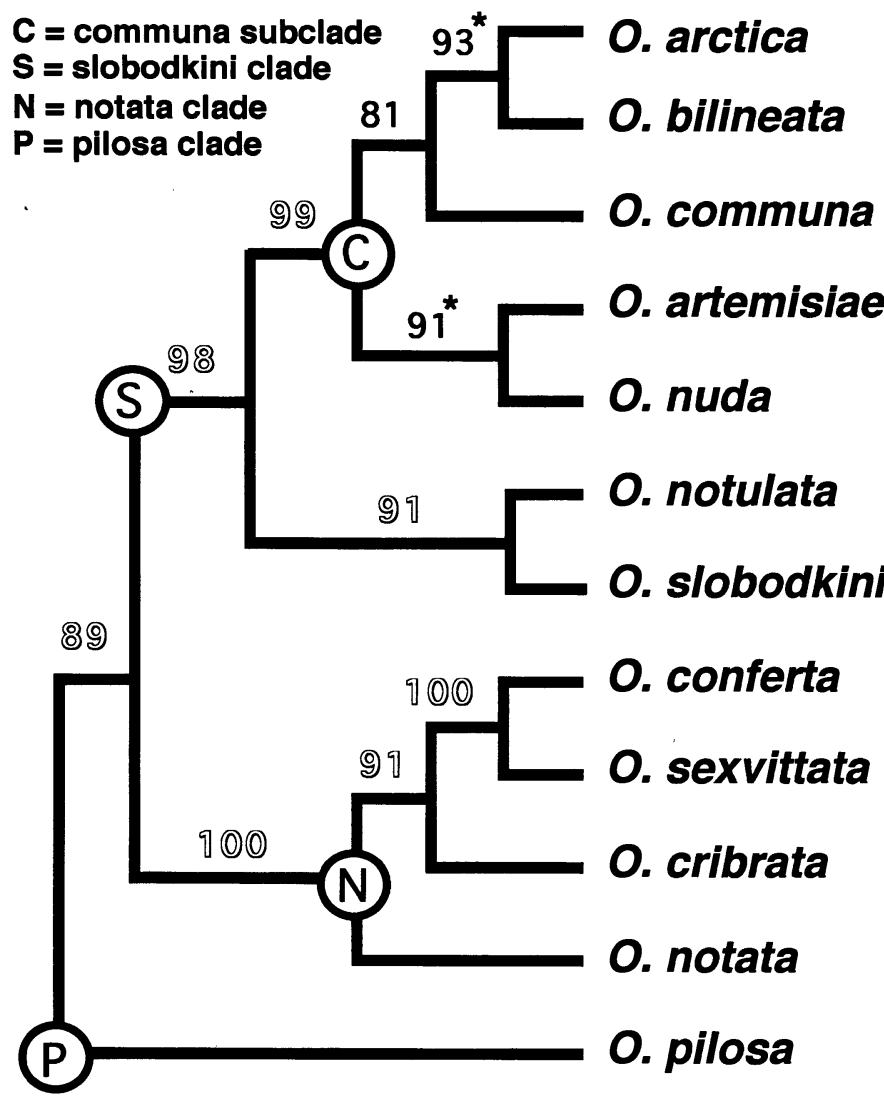

FIG. 1. Phylogenetic relationships among the species of Ophraella (for details of analysis, see the text and Funk et al. 1995). Outlined numbers are bootstrap proportions from combined-approach analysis; black numbers are bootstrap proportions from the analysis of mtDNA only, with transversions weighted either 1.1 (asterisks) or 3 times as heavily as transitions. Letters indicate clades referred to in this paper.

\section{Materials AND Methods}

The Study System.-Ophraella (Wilcox 1965) is a strictly North American genus of chrysomelid leaf beetles with 14 currently recognized species (Futuyma 1990, 1991; LeSage 1986). All but two (O. americana and $O$. californiana) were included in our analysis. Ophraella larvae and adults feed on the foliage of composites, with various species recorded from ten genera belonging to four tribes of the Asteraceae (table 1). Individual species range from being strictly monophagous (feeding on a single host plant species) to using particular species from up to five host genera.

Phylogenetic Analysis.-Funk et al. (1995) describe the phylogenetic analysis of 866 base pairs of mitochondrial DNA from the large subunit ribosomal RNA gene (16S, 446 bp) and the cytochrome oxidase subunit I gene (COI, 420 $\mathrm{bp}$ ), collected from single specimens of each of the 12 Ophraella species in the present study. These data were analyzed using generalized parsimony, successive approximations, neighbor-joining, and maximum-likelihood methods, and confidence in the obtained topologies was assessed using the bootstrap (Felsenstein 1985), while a variety of weighting schemes were employed (under parsimony) to test the robustness of the phylogenetic estimate. Additionally, the 64 morphological and 144 allelomorphic characters from F\&M were reanalyzed, and all three data sets were ultimately combined in a combined-approach analysis (Kluge 1989). The topology employed in this paper (fig. 1) derives from these analyses. Finally, COI sequence data were collected and analyzed from additional specimens of most species (and from several geographic populations of $O$. communa) to assess intraspecific variation. We interpret some of the resulting phylogeographic patterns in this paper.

Evolutionary Inference.-From our revised phylogenetic estimate, we inferred the history of Ophraella host associations by treating the host affiliation of individual Ophraella 

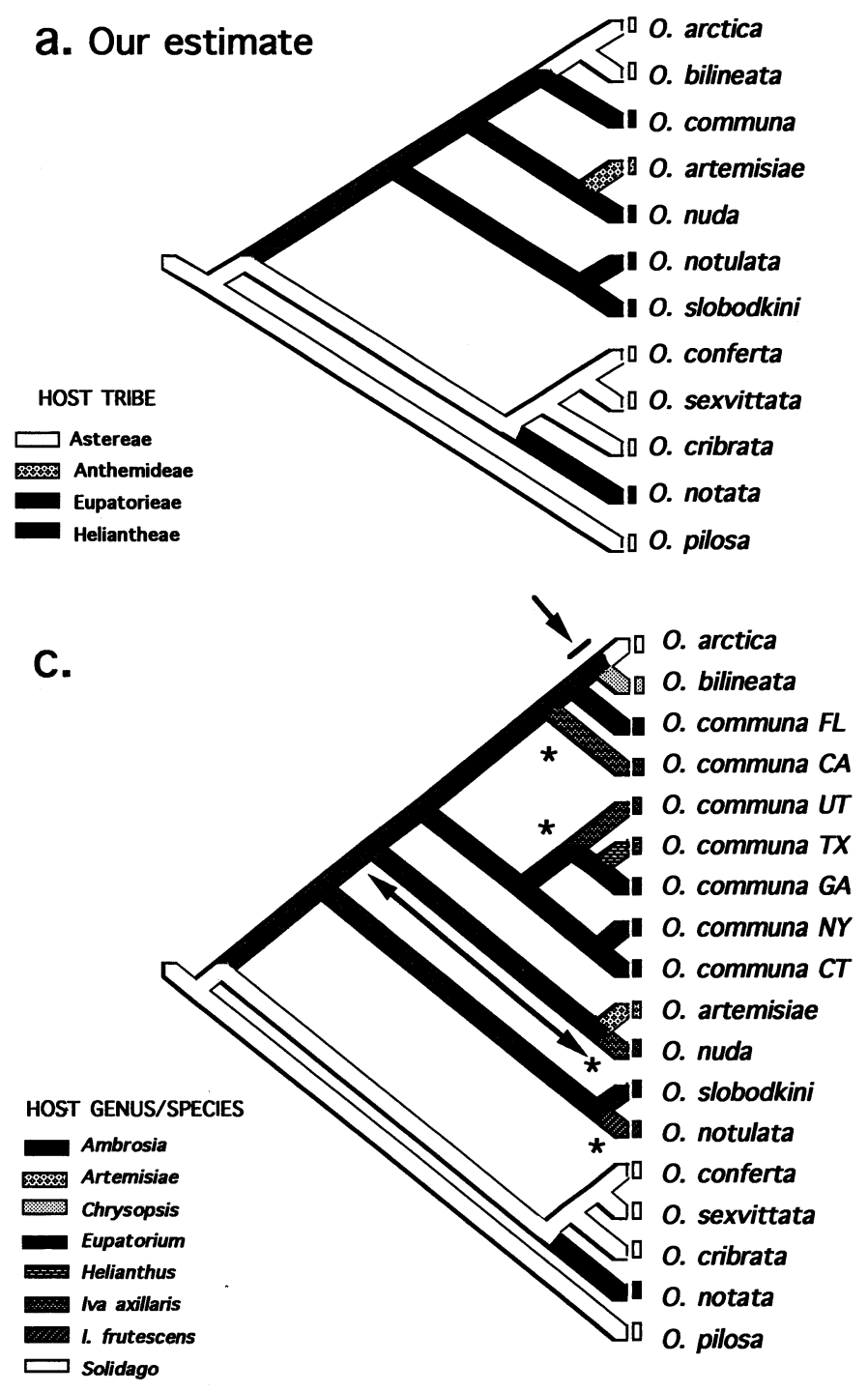
0. notulata
O. slobodkini
o. communa
O. bilineata
o. artemisiae
o. nuda
o. arctica
o. conferta
o. sexvittata
0. cribrata
o. notata
o. pilosa

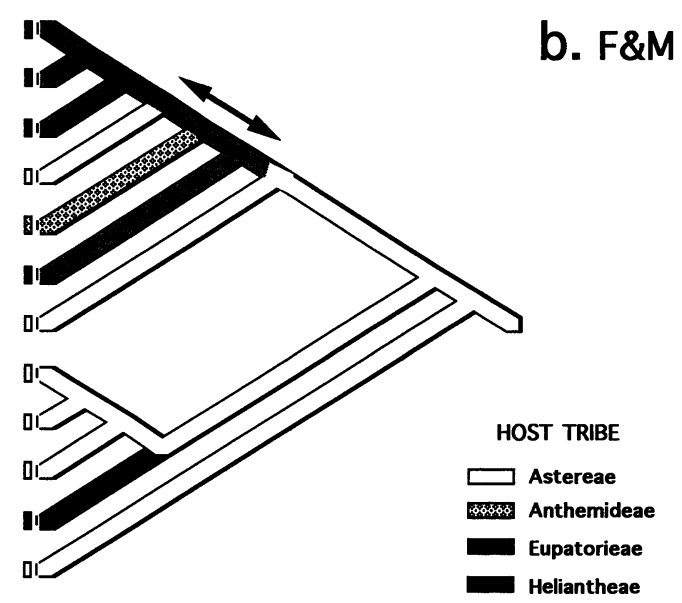

FIG. 2. A history of Ophraella host associations. (a) the single unambiguous history of host shifts among host tribes inferred by this study (four steps); (b) one of two equally parsimonious histories inferred by F\&M (using the ACCTRAN option in MacClade) (four steps); (c) our estimate of the history of host shifts among host genera and species (using the DELTRAN option in MacClade) (ten steps); (d) phylogenetic relationships among Ophraella host plant genera and tribes (see text for citations). Branches for which host optimization is equivocal when all most parsimonious reconstructions are considered are indicated with an arrow. Asterisks in (c) show the four inferred shifts from Ambrosia to Iva.

species as an unweighted multistate character and obtaining its most parsimonious reconstruction(s) using MacClade 3.01 (Maddison and Maddison 1992). In separate analyses, the tribal identity of host plants was optimized on a tree of Ophraella species, and the generic or specific identity of hosts was optimized on a tree which included relationships among various geographic populations of $O$. communa. We compare our inferred history of host use to that of F\&M to consider the reinterpretations that they necessitate; we compare it to the phylogenetic relationships of Ophraella's hosts to reexamine the possibility of cospeciation (fig. 2).

B. Farrell (in prep.) provided us with a COI molecular clock of $1.7 \%$ sequence divergence per million years, calibrated using palynological and biogeographic data for the genus Tetraopes (Cerambycidae). As Tetraopes belongs to the sister family of the chrysomelids, clock artifacts attributable to lineage-specific variation in substitution rate (reviewed in, e.g., Martin and Palumbi 1993) are likely to be minimal. This estimate is comparable to the $2.1 \%$ estimate inferred for arthropods in a recent survey of mtDNA clocks (Brower 1994 and references therein, e.g., Martin and Simon 1990; DeSalle and Templeton 1992; Knowlton et al. 1993).

Bearing in mind the remaining vagaries associated with molecular clocks (Hillis and Moritz 1990), we estimated divergence times between Ophraella clades from the observed range of COI sequence divergences (and their standard errors, provided by MEGA [Molecular Evolutionary Genetic Analysis]; Kumar et al. 1993), between haplotypes from these clades (table 2), corrected for multiple substitutions using Kimura's two-parameter model (Kimura 1980) from sequence 


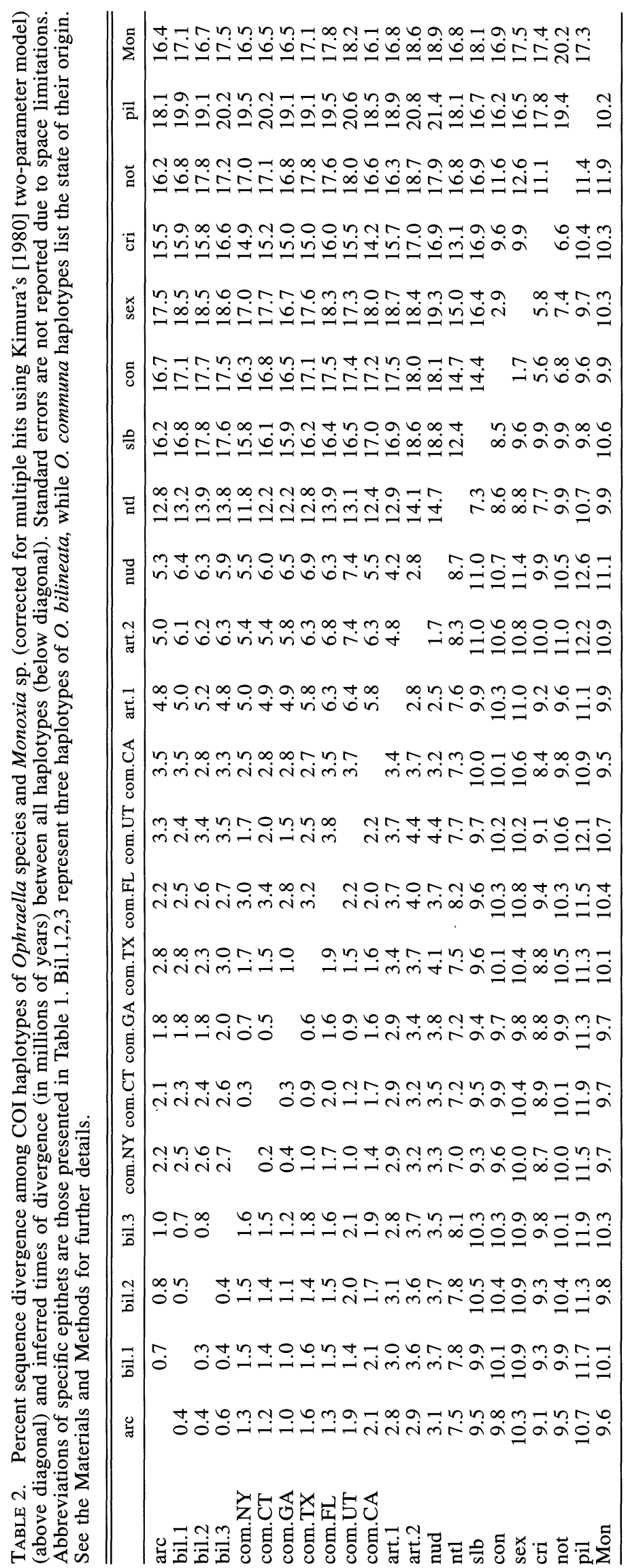


data collected in Funk et al. (1995). These divergence estimates allowed an examination of the temporal element of Ophraella diversification and host-use evolution.

\section{RESULTS AND Discussion}

\section{Phylogenetic Analysis}

Mitochondrial DNA analysis by all four phylogenetic algorithms yielded the same tree, with generally high bootstrap proportions supporting its nodes (fig. 1). This topology was also quite robust to changes in weighting scheme (for details, see Funk et al. 1995). The separate analyses of the morphology, allozyme, and mtDNA data sets yielded topologies that agreed on all relationships except those within the "slobodkini clade." Combined-approach analysis provided yet stronger bootstrap support for these agreed-upon groupings and confidently placed $O$. notulata and $O$. slobodkini as sister taxa basal to the "communa subclade." However, the combined approach provided inconsistent estimates of relationships within the communa subclade and little bootstrap support for these relationships, possibly because of heterogeneous rates of evolution among data sets (Funk et al. 1995).

The phylogenetic estimate for Ophraella that we derived for use in the present study (fig. 1) thus adopts the combinedapproach topology for all relationships except those within the communa subclade. For these, the mtDNA topology (see fig. 2c in Funk et al. 1995) was employed as mtDNA provides the only estimates of these relationships that were robust and strongly supported by bootstrap. The Ophraella topology that we use thus differs from the mtDNA tree only in the joining of $O$. notulata and $O$. slobodkini as sister taxa. (This grouping was recovered in certain analyses of mtDNA as well, but in others $O$. notulata and $O$. slobodkini were successively basal to the communa subclade.)

\section{History of Ophraella Host Associations}

This study was undertaken primarily to provide a more confident estimate of the history of host associations in the genus Ophraella. Our reconstruction of this history at the host-tribe level provides an unambiguous estimate, identical in length and in inferred host shifts to the findings of $F \& M$ (fig. 2a,b). Under parsimony, the reconstructions from both studies necessitate one host shift from Astereae to Eupatorieae, one from Astereae to Heliantheae, one from Heliantheae to Anthemideae, and one reversal from Heliantheae to Astereae. (F\&M had favored this reconstruction over an equally parsimonious alternative on the presumption that one shift from the chemically simple Astereae to the chemically formidable Heliantheae followed by a reversal was more plausible than two independent shifts to Heliantheae.)

New Interpretations. - These similarities, however, belie important reinterpretations of (1) cladistic proximity, (2) lineage-specific host associations, and (3) the timing of realized host shifts that our results require. Examples illustrate each of these: (1) F\&M suggested a close relationship between $O$. communa and $O$. notulata/O. slobodkini, whereas we find these taxa to be cladistically and genetically divergent. (2) Although F\&M inferred that $O$. arctica has never been associated with Heliantheae hosts, we find that it has only re- cently (0.8-1.8 mya) shifted to the Astereae after a prolonged Heliantheae affiliation of 4.3-11.7 my. (3) Although both studies agree on the sister species status of $O$. notulata and $O$. slobodkini and on their history of host use, we infer a much more ancient host shift from Ambrosia to Iva (>5.7 my versus $\ll 1$ my) by $O$. notulata.

Such findings have important implications for the interpretion of our experimental studies. On the hypothesis that host shifts are constrained by genetic variation, the phylogenetic inference of a particular host shift predicts that the shifted lineage is more likely to exhibit genetic variation in performance on the plant from which it shifted than on plants with which it has never been affiliated (Futuyma et al. 1993, 1995). Genetic variation, however, might be expected to decline over evolutionary time in the absence of selection for its maintenance (Futuyma and Keese 1992; Rausher 1992). Because species that have more recently switched hosts are more likely to retain the genetic variation that facilitated this shift, the capacity to test these predictions may depend on how long ago a shift occurred. Thus, having a confident estimate of realized host shifts and their timing is essential.

Reconstruction at Different Taxonomic Levels.-Our results also illustrate the utility of employing multiple levels of both phylogenetic resolution and character coding in the cladistic study of character evolution. Although tribal host affiliation appears to be relatively conserved, the optimization of host genus and species on a more highly resolved phylogeny reveals a history of frequent host shifts between plants in the Heliantheae (fig. 2c). These include one shift from Ambrosia artemisiifolia to Helianthus and four independent shifts from A. artemisiifolia to Iva, three of these to I. axillaris. (It is unknown whether Ambrosia is also used by the $O$. communa populations for which shifts were inferred.) Given the frequency of these shifts, their specificity, consistent polarity, and occurrence in habitats as diverse as the northern plains $(O . n u d a)$, the southeast $(O$. notulata) and the arid west ( $O$. communa; Utah, California) are striking, and support the notion that constraints do play an important role in determining which shifts are possible. Only by further dissecting the hostplant character and using a more finely resolved phylogeny was the pattern of parallelism exposed. Interestingly, Ophraella provides evidence for constraints in terms of the infrequency of shifts at one level of taxonomic resolution and in terms of their frequency at another.

Sources of Ambiguity in Reconstruction.-Though character reconstruction techniques can be used to study a multitude of questions about the origins, history, and correlations of characters (reviewed in Maddison 1994), statements about these inferences must be tempered by an assessment of their reliability. Rigorous methods of assessing this likelihood have not yet been offered. However, robustness of the hypothesis under test to various perturbations of phylogenetic assumptions may provide one measure of confidence (reviewed in Swofford and Maddison 1992; Maddison 1994). One way to do this is by comparing reconstructions on competing topologies. A second is to test the sensitivity of the hypothesis to the addition and deletion of taxa. A third is to compare equally or nearly equally parsimonious reconstructions.

These three approaches suggest that our estimate of tribal 
host shifts is robust. As mtDNA provided a single, highly supported tree and a single unambiguous history of shifts, no competing histories are equally parsimonious (although it must be noted that reconstructions entailing but a single extra step provide altered interpretations of character [here, host use] evolution, a distressingly common feature of character optimization). Further, among those (few) alternative relationships found under various weighting schemes (Funk et al. 1995), the only one affecting host-use history placed $O$. arctica and $O$. communa/O. bilineata as sister taxa (a change that yields two equally parsimonious reconstructions, each entailing an additional host shift). Although the addition of a single hypothetical taxon, with each possible host affiliation, to each branch of the topology yielded ambiguous host-use histories in a small proportion of the possible placements, our proposed history was robust to the deletion of any single Ophraella species.

We are less confident in the history of shifts among particular host genera and species within tribes by members of the slobodkini clade. COI did not provide enough information (table 2) to support strongly some relationships within $O$. communa (fig. 3). Furthermore, the reconstructed history was not entirely unambiguous (fig. 2c) and was sensitive to the deletion of certain OTUs (operational taxonomic units). Nonetheless, these concerns do not compromise the most important inference drawn from this analysis, namely, that multiple shifts have occurred between Ambrosia and Iva. Our confidence in the phylogeny of Ophraella species (fig. 1) strongly supports the inference of at least three shifts, while the well-supported cladistic separation of the Iva-feeding California and Utah populations (fig. 3) of O. communa suggests that a fourth shift is likely.

\section{Tempo and Mode of Evolutionary Diversification in Ophraella}

Timing of Ophraella Radiation.-Our COI-generated estimates of Ophraella divergence events (table 2) are generally considerably more ancient than those inferred by F\&M using Nei's calibration (Nèi 1987) of allozyme distances. (F\&M also pointed out that Sarich (1977) and Thorpe (1982) offered a more extreme calibration; this yields estimates closer to those of COI.) Although F\&M found all but the most basal cladogenetic event to have been of Pliocene or Quaternary origin, the COI data imply that all divergences but the communa subclade radiation and the $O$. conferta-O. sexvittata event date to Miocene times, with the Monoxia-Ophraella split occurring 8.3-13.4 mya (as compared with the 5.5-7.7 my estimate of F\&M). An extreme example of this disparity between estimates is provided by F\&M's inference that the slobodkini clade included very closely related species that diverged from one another only 1-2 mya. We estimated the communa subclade itself to be 2.1-4.5 my old, and the divergence between this lineage and that of $O$. notulata/O. slobodkini to have occurred 6.1-12.5 mya. Moreover, the most ancient divergence among $O$. communa haplotypes $(2.1 \pm$ $0.6 \mathrm{my}$ ) also exceeds the F\&M slobodkini clade estimate. The finding that $O$. notulata/O. slobodkini are nearly as genetically divergent from members of the communa subclade (minimally $7.5 \%$ overall) as from those of the notata clade (minimally $8.4 \%$ overall) suggests that this lineage split off very early in the history of the slobodkini clade. This, in turn, shows that the shift from Astereae to Heliantheae was ancient rather than very recent, and implies a long history of Heliantheae feeding by Ophraella.

Discordance between Genetic and Morphological Divergence.-Ophraella represents a rather morphologically homogeneous genus of beetles, the species of which differ in fairly subtle aspects. Thus, the discovery of unusually high levels of COI divergence (up to $20.8 \%$ among species and $3.8 \%$ within $O$. communa) was unexpected, although recent studies of mtDNA evolution in other phytophagous genera report similar findings (Boyce et al. 1994; Brown et al. 1994; B. Farrell in prep.). The decoupling of morphological and molecular evolution in Ophraella is further supported by the finding that the morphological sibling species $O$. notulata and $O$. slobodkini (whose species status was first confirmed electrophoretically; Futuyma 1991) appear to have speciated 5.7-8.9 mya. These two species exhibit more than twice as much overall sequence divergence as the most divergent species within the communa subclade. Despite this differentiation, one of the reciprocal crosses between these species produces viable although apparently infertile hybrid offspring in the laboratory (Keese 1994), suggesting that full reproductive isolation has evolved very slowly (cf. Coyne and Orr 1989). Nonetheless, both electrophoretic analysis (F\&M) and the monophyly of each species, revealed by our analysis of several populations (Funk et al. 1995), suggest only limited gene flow between them.

An example of the opposite trend is also intriguing. Ophraella nuda and $O$. artemisiae are morphologically dissimilar species that exhibited relatively little genetic differentiation in our study. Indeed, $O$. artemisiae appears to be paraphyletic with respect to $O$. nuda, a relationship strongly supported by bootstrap (fig. 3). An even more striking case of the paraphyly of mtDNA lineages is offered by the morphologically coherent $O$. communa with respect to $O$. bilineata/O arctica. Generalized parsimony and neighbor-joining analyses agree on this paraphyly and neighbor joining supports it with 64 bootstrap replicates. Rather few instances of paraphyletic species (e.g., Avise et al. 1983; Avise et al. 1990; Powell 1991; Melnick et al. 1993; Moran and Kornfield 1993) have yet been reported in the literature.

Mechanisms of Speciation.-Based on the biogeography of morphologically divergent populations and species, Mayr $(1954,1963)$ suggested that species frequently originate by divergence of localized peripheral populations, a process he later termed peripatric speciation (Mayr 1982). Under this model, new species will often be more closely related to certain populations of the "parent species" than some populations of the latter are to each other. Given the geographic distributions and host affiliations (table 1) of $O$. artemisiae and $O$. nuda, of $O$. communa and $O$. bilineata/O. arctica, and of $O$. bilineata and $O$. arctica, the relationships among their haplotypes in each instance suggest phylogeographic structure (Avise et al. 1987) consistent with the peripatric scenario (fig. 3). In each case, the former taxon has a known distribution that is much larger than, adjacent to, and largely nonoverlapping with, that of the latter taxon, the origin of which is associated with a host shift (fig. 2c). These patterns are 

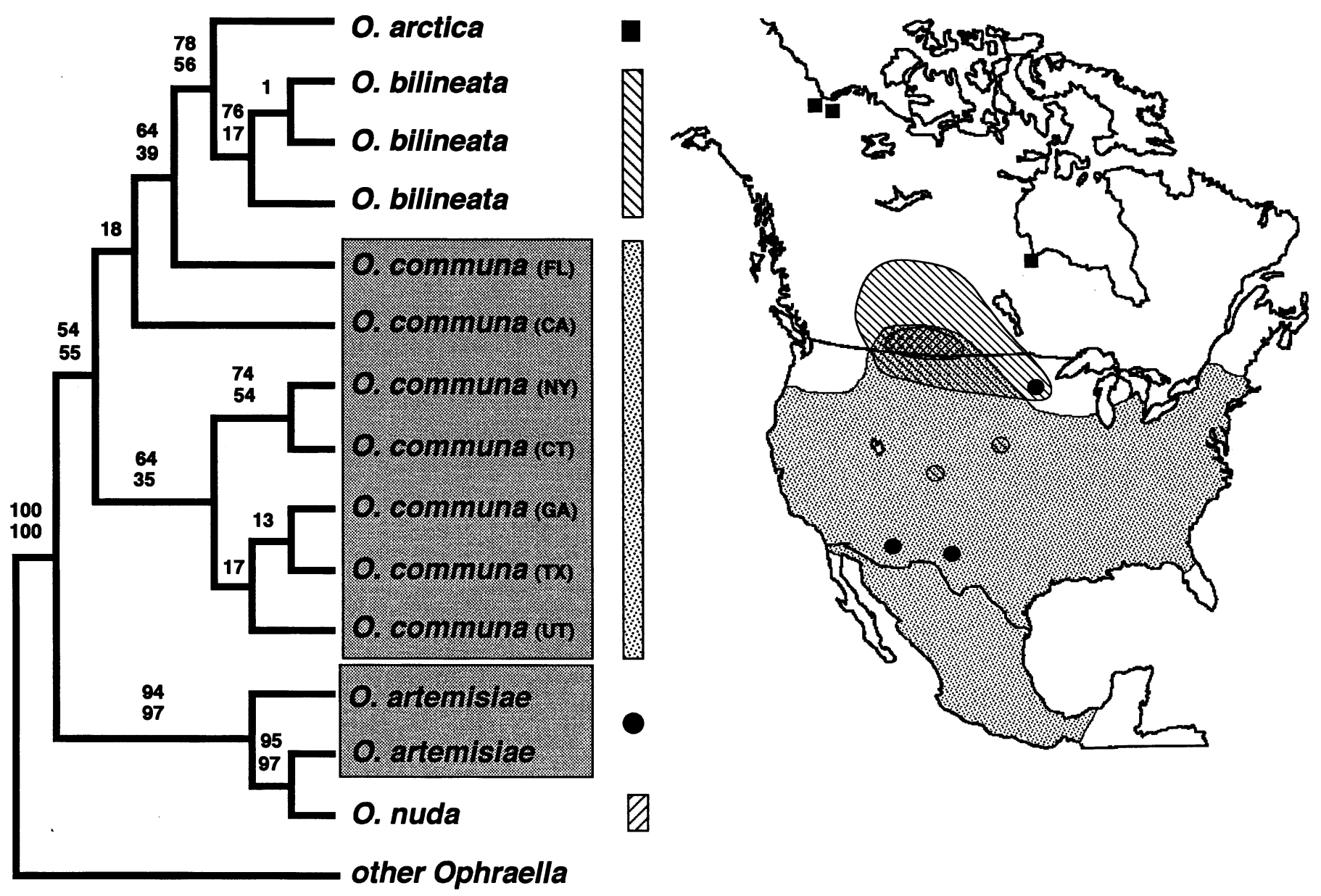

FIG. 3. Cladistic and biogeographic relationships among members of the communa subclade. This tree derives from a $50 \%$ majority rule consensus of 100 bootstrap replicates from the unweighted analysis of 420 base pairs of cytochrome oxidase I. Two sets of bootstrap proportions are provided. The lower are from the parsimony analysis used to generate the tree; the upper are from neighbor-joining analysis (where the topologies of the two agree). The topology presented is compatible with the strict consensus of 24 equally shortest trees, the latter differing only in its lack of resolution among the Georgia, Texas, Utah, and New York/Connecticut populations of Ophraella communa. The apparent paraphyly of $O$. communa and $O$. artemisiae is highlighted by shading. Patterns following taxon names are those used to illustrate geographic distributions of these species in the accompanying map. Ophraella arctica and $O$. artemisiae have been collected from three localities each. Distributions from LeSage (1986), Futuyma (1990), and personal records.

thus consistent with a model of speciation via adaptation of a peripheral isolate to a novel selection regime, yielding rapid differentiation as a by-product.

In a recent study of prodoxid moths, Brown et al. (1994) similarly found evidence suggestive of paraphyletic species in each of two cases in which the derived species was associated with a host shift. Given the current availability of mtDNA sequence data, the phylogeographic approach (Avise et al. 1987), in combination with ecological data such as host associations, provides a potentially powerful means of identifying systems for the study of evolutionary divergence and radiation. In future work, we plan to characterize both the origin of $O$. bilineata from $O$. communa and the nature of the associated host shift.

Other possible explanations for the observed paraphyly certainly cannot be discounted. Hybridization at the geographic borders of these parapatrically distributed species could account for the observed relationships, although the important differences in host association between these forms reduces the plausibility of this argument, as does the apparent lack of gene flow between neighboring populations of $O$. notulata and $O$. slobodkini, which have closely related host plants. Likewise, incomplete lineage sorting (Avise and Ball 1990) of haplotypes from ancestrally polymorphic species remains a viable explanation.

Evidence on Cospeciation.-Within the Asteraceae, Ambrosia and Artemisia are considered highly derived genera (Heywood et al. 1977; Bremer 1994). Yet, palynological records reveal their existence from at least the Early and Middle Miocene, respectively (Muller 1981). Based on this information, F\&M considered Ophraella too young to have cospeciated with its hosts. Despite our calculation of a more ancient and largely Miocene history of Ophraella diversification, our phylogenetic data provide three classes of evidence which demonstrate that cospeciation does not provide a general explanation for Ophraella host associations: (1) 
Certain host divergences greatly pre-date beetle divergences, for example, the recent shift from Ambrosia to Artemisia (1.5$5 \mathrm{my}$ ) by $O$. artemisiae. (2) The host loyalty requisite for cospeciation is not universal, for example, the reversal to Astereae and the parallel colonizations of Iva. (3) The lack of congruence between host (Jansen et al. 1990, 1991; Kim et al. 1990; Bremer et al. 1992; Bremer 1994) and beetle phylogenies (fig. 2a,d) suggests that even certain host associations with a single origin have been initiated by active host shift rather than by passive cospeciation, for example, the shift of $O$. notata from Astereae to Eupatorieae.

It must also be noted that a number of the asteraceous tribes that include no Ophraella hosts are cladistically interspersed with those that do (Bremer 1994), and that only a small fraction of the species within host-including tribes are actually fed upon. Thus, one would have to posit a relictual status for Ophraella to argue for an important role for cospeciation even if host-phytophage phylogenies were completely congruent (Brooks and Bandoni 1988). Given that Ophraella is a relatively young group with a limited geographic range and a comparably diverse sister genus (Monoxia, Blake 1939), this explanation is implausible. Although one might salvage a role for cospeciation by invoking the extinction of lineages with intervening host associations or by positing that previous bouts of parallel cladogenesis have been obscured by more recent host shifts, our study offers little clear evidence for its importance for Ophraella.

Our results thus agree with a growing consensus that parallel cladogenesis rarely explains the current host associations of herbivorous insects (Mitter and Farrell 1991; Brown et al. 1994). Although non-phytophagous parasites may indeed commonly cospeciate (Mitter and Brooks 1983), the more facile dispersal of herbivores may dictate that host shifts largely account for macroevolutionary trends of herbivore diversity and host use. We recommend that future studies of host-phytophage systems consider the biogeographic and temporal elements of diversification and host-use evolution as a means of expanding the explanatory scope of the coevolutionary paradigm.

\section{ACKNOWLEDGMENTS}

We thank P. Wilson, L. Shapiro, and two anonymous reviewers for valuable comments on earlier drafts of this paper. Support by the National Science Foundation (BSR-8817912) is gratefully acknowledged. This is Contribution 917 in Ecology and Evolution from the State University of New York at Stony Brook.

\section{LiteratuRE Cited}

Avise, J. C., and R. M. Ball, Jr. 1990. Principles of genealogical concordance in species concepts and biological taxonomy. Oxford Surveys in Evolutionary Biology 7:45-67.

Avise, J. C., J. F. Shapira, S. W. Daniel, C. F. Aquadro, and R. A. Lansman. 1983. Mitochondrial DNA differentiation during the speciation process in Peromyscus. Molecular Biology and Evolution 1:38-56.

Avise, J. C., J. Arnold, R. M. Ball, E. Bermingham, T. Lamb, J. E. Neigel, C. A. Reeb, and N. C. Saunders. 1987. Intraspecific phylogeography: the mitochondrial DNA bridge between population genetics and systematics. Annual Review of Ecology and Systematics 18:489-522.
Avise, J. C., C. D. Ankney, and W. S. Nelson. 1990. Mitochondrial gene trees and the evolutionary relationships of mallard and black ducks. Evolution 44:1109-1119.

Benson, W. W., K. S. Brown, Jr., and L. E. Gilbert. 1975. Coevolution of plants and herbivores: passion flower butterflies. Evolution 29:659-680.

Blake, D. H. 1939. A study of LeConte's types of the beetles in the genus Monoxia, with descripions of new species. Proceedings of the United States National Museum 87:145-169.

Boyce, T. M., M. E. Zwick, and C. F. Aquadro. 1994. Mitochondrial DNA in the bark weevils: phylogeny and evolution in the Pissodes strobi species group (Coleoptera: Curculionidae). Molecular Biology and Evolution 11:183-194.

Bremer, K. 1994. Asteraceae: cladistics and classification. Timber Press, Portland, Oreg.

Bremer, K., R. K. Jansen, P. O. Karis, M. Kallersjö, S. C. Keeley, K.-J. Kim, H. J. Michaels, J. D. Palmer, and R. S. Wallace. 1992. A review of the phylogeny and classification of the Asteraceae. Nordic Journal of Botany 12:141-148.

Brooks, D. R. 1979. Testing the context and extent of host-parasite coevolution. Systematic Zoology 28:299-307.

. 1988. Macroevolutionary comparisons of host and parasite phylogenies. Annual Review of Ecology and Systematics 19: 235-259.

Brooks, D. R., and S. M. Bandoni. 1988. Coevolution and relicts. Systematic Zoology 37:19-33.

Brooks, D. R., and D. A. McLennan. 1991. Phylogeny, ecology, and behavior: a research program in comparative biology. University of Chicago Press, Chicago.

- 1993. Parascript: parasites and the language of evolution. Smithsonian Institution Press, Washington, D.C..

Brower, A. V. Z. 1994. Rapid morphological radiation and convergence among races of the butterfly Heliconius erato, inferred from patterns of mitochondrial DNA evolution. Proceedings of the National Academy of Sciences, USA 91:6491-6495.

Brown, J. M., O. Pellmyr, J. N. Thompson, and R. G. Harrison. 1994. Phylogeny of Greya (Lepidoptera: Prodoxidae) based on nucleotide sequence variation in mitochondrial cytochrome oxidase I and II: congruence with morphological data. Molecular Biology and Evolution 11:128-141.

Coyne, J. A., and H. A. Orr. 1989. Patterns of speciation in Drosophila. Evolution 43:362-381.

DeSalle, R., and A. R. Templeton. 1992. The mtDNA genealogy of closely related Drosophila silvestris. Journal of Heredity 83: 211-216.

Dethier, V. G. 1954. Evolution of feeding preferences in phytophagous insects. Evolution 8:833-854.

Ehrlich, P. R., and P. H. Raven. 1964. Butterflies and plants: a study in coevolution. Evolution 18:586-608.

Farrell, B., and C. Mitter. 1990. Phylogenesis of insect/plant interactions: have Phyllobrotica leaf beetles (Chrysomelidae) and the Lamiales diversified in parallel? Evolution 44:1389-1403.

Feeny, P. 1992. The evolution of chemical ecology: contributions from the study of herbivorous insects. Pp. 1-44 in G. A.Rosenthal and M. R. Berenbaum, eds. Herbivores: their interactions with secondary plant metabolites, $2 \mathrm{~d}$ ed. Academic Press, San Diego, Calif.

Felsenstein, J. 1985. Confidence limits on phylogenies: an approach using the bootstrap. Evolution 39:783-791.

Funk, D. J., D. J. Futuyma, G. Ortí, and A. Meyer. 1995. Mitochondrial DNA sequences and multiple data sets: a phylogenetic study of phytophagous beetles (Chrysomelidae: Ophraella). Molecular Biology and Evolution 12:627-640.

Futuyma, D. J. 1983. Selective factors in the evolution of host choice by phytophagous insects. Pp. 227-244 in S. Ahmad, ed. Herbivorous insects: host-seeking behavior and mechanisms. Academic Press, New York.

. 1990. Observations on the taxonomy and natural history of Ophraella Wilcox (Coleoptera: Chrysomelidae), with a description of a new species. Journal of the New York Entomological Society 98:163-186.

. 1991. A new species of Ophraella Wilcox (Coleoptera: 
Chrysomelidae) from the southeastern United States. Journal of the New York Entomological Society 99:643-653.

1992. Genetics and the phylogeny of insect-plant interactions. Pp. 191-200 in S. B. J. Menken, J. H. Visser, and P. Harrewijn, eds. Proceedings of the 8th International Symposium on Insect-Plant Relationships. Kluwer Academic, Dordrecht.

Futuyma, D. J., and M. C. Keese. 1992. Evolution and coevolution of plants and phytophagous arthropods. Pp. 439-475 in G. A. Rosenthal, and M. R. Berenbaum, eds. Herbivores: their interactions with secondary plant metabolites, 2E. Academic Press, London.

Futuyma, D. J., and S. S. McCafferty. 1990. Phylogeny and the evolution of host plant associations in the leaf beetle genus Ophraella (Coleoptera: Chrysomelidae). Evolution 44:18851913.

Futuyma, D. J., M. C. Keese, and S. J. Scheffer. 1993. Genetic constraints and the phylogeny of insect-plant associations: responses of Ophraella communa (Coleoptera: Chrysomelidae) to host plants of its congeners. Evolution 47:888-905.

Futuyma, D. J., J. Walsh, T. Morton, D. J. Funk, and M. C. Keese. 1994. Genetic variation in a phylogenetic context: responses of two specialized leaf beetles (Coleoptera: Chrysomelidae) to host plants of their congeners. Journal of Evolutionary Biology 7: 127-146.

Futuyma, D. J., M. C. Keese, and D. J. Funk. 1995. Genetic constraints on macroevolution: the evolution of host affiliation in the leaf beetle genus Ophraella. Evolution 49:797-809.

Harvey, P. H., and M. D. Pagel. 1991. The comparative method in evolutionary biology. Oxford University Press, Oxford.

Heywood, V. H., J. B. Harborne, and B. L. Turner, eds. 1977. The biology and chemistry of the Compositae. Academic Press, London.

Hillis, D. M., and C. Moritz. 1990. An overview of applications of molecular systematics. Pp. 502-515 in D. M. Hillis and C. Moritz, eds. Molecular systematics. Sinauer, Sunderland, Mass.

Jansen, R. K., K. E. Holsinger, H. J. Michaels, and J. D. Palmer. 1990. Phylogenetic analyses of chloroplast DNA restriction site data at higher taxonomic levels: an example from the Asteraceae. Evolution 44:2089-2105.

Jansen, R. K., H. J. Michaels, and J. D. Palmer. 1991. Chloroplast DNA variation in the Asteraceae: phylogenetic and evolutionary implications. Pp. 252-279 in D. Soltis, P. Soltis, and J. Doyle, eds. Molecular systematics of plants. Chapman and Hall, New York.

Jermy, T. 1984. Evolution of insect/host-plant relationships. American Naturalist 124:109-113.

Keese, M. C. 1994. Genetic and ecological determinants of host range in leaf feeding beetles (Coleoptera: Chrysomelidae). Ph.D. diss. State University of New York at Stony Brook.

Kim, K.-J., B. L. Turner, and R. K. Jansen. 1990. Chloroplast DNA evidence for the phylogenetic relationships among Coreopsideae, Eupatorieae, Gaillardieae, Heliantheae, and Tageteae. American Journal of Botany Supplement 77:140-141. (Abstract)

Kimura, M. 1980. A simple method for estimating evolutionary rate of base substitution through comparative studies of nucleotide sequences. Journal of Molecular Evolution 16:111-120.

Kluge, A. G. 1989. A concern for evidence and a phylogenetic hypothesis of relationships among Epicrates (Boidae, Serpentes). Systematic Zoology 38:7-25.

Knowlton, N., L. A. Weigt, L. A. Solorzano, D. K. Mills, and E. Bermingham. 1993. Divergence in proteins, mitochondrial DNA, and reproductive compatibility across the Isthmus of Panama. Science 260:1629-1632.

Kumar, S., K Tamura, and M. Nei. 1993. MEGA: molecular evolutionary genetic analysis. Pennsylvania State University, University Park, $\mathrm{Pa}$.

Lauder, G. V. 1990. Functional morphology and systematics: studying functional patterns in an historical context. Annual Review of Ecology and Systematics 21:317-340.

LeSage, L. 1986. A taxonomic monograph of the Nearctic galerucine genus Ophraella Wilcox (Coleoptera: Chrysomelidae). Memoirs of the Entomological Society of Canada No. 133:1-75.

Maddison, D. R. 1994. Phylogenetic methods for inferring the evolutionary history and processes of change in discretely valued characters. Annual Review of Entomology 39:267-292.

Maddison, W. P., and D. R. Maddison. 1992. MacClade: analysis of phylogeny and character evolution. Version 3.0. Sinauer, Sunderland, Mass.

Martin, A. P., and S. R. Palumbi. 1993. Body size, metabolic rate, generation time, and the molecular clock. Proceedings of the National Academy of Sciences, USA 90:4087-4091.

Martin, A., and C. Simon. 1990. Differing levels of among-population divergence in the mitochondrial DNA of periodical cicadas related to historical biogeography. Evolution 44:10661080.

Mayr, E. 1954. Change of genetic environment and evolution. Pp. 157-180 in J. Huxley, A. C. Hardy, and E. B. Ford, eds. Evolution as a process. Allen and Unwin, London.

. 1963. Animal species and evolution. Harvard University Press, Cambridge, Mass.

1982. Processes of speciation in animals. Pp. 1-19 in C. Barigozzi, ed. Mechanisms of speciation. Alan R. Liss, New York.

Melnick, D. J., G. A. Hoelzer, R. Absher, and M. V. Ashley. 1993. mtDNA diversity in rhesus monkeys reveals overestimates of divergence time and paraphyly with neighboring species. Molecular Biology and Evolution 10:282-295.

Miller, J.S. 1991. Host-plant associations among prominent moths. Bioscience 42:50-57.

Mitter, C., and D. R. Brooks. 1983. Phylogenetic aspects of coevolution. Pp. 65-98 in D. J. Futuyma and M. Slatkin, eds. Coevolution. Sinauer, Sunderland, Mass.

Mitter, C., and B. D. Farrell. 1991. Macroevolutionary aspects of insect/plant interactions. Pp. 35-78 in E. Bernays, ed. Insect/ plant interactions, Vol. 3. CRC Press, Boca Raton, Fla.

Mitter, C., B. D. Farrell, and D. J. Futuyma. 1991. Phylogenetic studies of insect/plant interactions: insights into the genesis of diversity. Trends in Ecology and Evolution 6:290-293.

Moran, P., and I. Kornfield. 1993. Retention of an ancestral polymorphism in the Mbuna species flock (Teleostei: Cichlidae) of Lake Malawi. Molecular Biology and Evolution 10:1015-1029.

Muller, J. 1981. Fossil pollen records of extant angiosperms. Botanical Review 47:1-142.

Nei, M. 1987. Molecular evolutionary genetics. Columbia University Press, New York.

Powell, J. R. 1991. Monophyly/paraphyly/polyphyly and gene/species trees: an example from Drosophila. Molecular Biology and Evolution 8:892-896.

Rausher, M. D. 1992. Natural selection and the evolution of plantinsect interactions. Pp. 20-88 in B. D. Roitberg and M. B. Isman, eds. Insect chemical ecology. Chapman and Hall, New York.

Sarich, V. M. 1977. Rates, sample sizes, and the neutrality hypothesis for electrophoresis in evolutionary studies. Nature 265:24-28.

Spencer, K. C. 1988. Chemical mediation of coevolution in the Passiflora-Heliconius interaction. Pp. 167-240 in K. C. Spencer, ed. Chemical mediation of coevolution. Academic Press, San Diego, Calif.

Swofford, D. L., and W. P. Maddison. 1992. Parsimony, characterstate reconstructions, and evolutionary inferences. Pp. 186-223 in R.L. Mayden, ed. Systematics, historical ecology, and North American freshwater fishes. Stanford University Press, Stanford, Calif.

Thorpe, J. P. 1982. The molecular clock hypothesis: biochemical evolution, genetic differentiation and systematics. Annual Review of Ecology and Systematics 13:139-168.

Wanntorp, H.-E., D. R. Brooks, T. Nilsson, S. Nylin, F. Ronquist, S. C. Stearns, and N. Wedell. 1990. Phylogenetic approaches in ecology. Oikos 57:119-132.

Ward, L. K., and D. F. Spalding. 1993. Phytophagous British insects and mites and their food-plant families: total numbers and polyphagy. Biological Journal of the Linnean Society 49:257-276.

Wilcox, J. A. 1965. A synopsis of North American Galerucinae (Coleoptera: Chrysomelidae). Bulletin of the New York Museum and Science Service 400:1-226.

Corresponding Editor: D. Schluter 


\section{APPENDIX}

\section{Locality Data}

Collection localities and host plants of origin for specimens used in this study. In parentheses are the number of sequenced specimens sharing a COI haplotype for species illustrated in figure 3. Additional specimens were also sequenced for other Ophraella species, as reported by Funk et al. (1995).

Ophraella arctica: Canada, N.W.T., Inuvik, Solidago multiradiata (1); O. artemisiae: Minn., Anoka Co., Bethel, Artemisia ludoviciana (2); O. bilineata: Canada, Sask., Chaplin, Chrysopsis villosa $(1,1)$; Mont., Cascade Co., Cascade, C. villosa (1); O. communa: Calif., San Diego Co., Kitchen Creek, Ambrosia psilostachya (1); Calif., Inyo Co., Antelope
Spring, Iva axillaris (2, same haplotype as from Kitchen Creek); Conn., Fairfield Co., Reading, Ambrosia artemisiifolia (1); Fla., Leon Co., Iamonia, A. artemisiifolia (3); Ga., Tift Co., Tifton, A. artemisiifolia (1); N.Y., Suffolk Co., Stony Brook (1); Tex., Reeves Co., Balmorhea, $\mathrm{He}$ lianthus ciliaris (1); Utah, Uintah Co., Vernal, I. axillaris (2); $O$. conferta: N.Y., Tompkins Co., Ithaca, Solidago altissima; $O$. cribrata: N.Y., Suffolk Co., Manorville, Solidago juncea; $O$. notata: N.Y., Tompkins Co., Ithaca, Eupatorium perfoliatum; O. notulata: S.C., Beaufort Co., Bluffton, Iva frutescens; O. nuda: Canada, Alta., Pakowki L., Iva axillaris (2); $O$. pilosa: N.Y., Tompkins Co., Ithaca, Aster sagittifolius; $O$. sexvittata: Fla., Dixie Co., Jena, Solidago leavenworthii; O. slobodkini: Fla., Leon Co., Iamonia, Ambrosia artemisiifolia; Monoxia sp.: Fla., Wakulla Co., St. Mark's National Wildlife Refuge, Lycium carolinense; Exema neglecta: Fla., Tampa, Baccharis halimifolia. 